Commentary

\title{
CIAM and Its Outcomes
}

\author{
Eric Mumford \\ Sam Fox School of Design and Visual Arts, Washington University, St. Louis, MO 63130, USA; E-Mail: epm@wustl.edu
}

Submitted: 28 July 2019 | Accepted: 28 July 2019 | Published: 30 September 2019

\begin{abstract}
CIAM, the Congrès Internationaux d'Architecture Moderne, founded by a coalition of European architects in 1928, was an international forum for new ideas about the urban design of housing and cities in an emerging socialist context. Its most influential concepts were the Existenzminimum, the small family housing unit affordable on a minimum wage income and the focus on CIAM 2, 1929; the design of housing settlements of such units, the focus of CIAM 3, 1930; and the Functional City, the idea that entire cities should be designed or redesigned on this basis. This article briefly explains these ideas and considers some of their subsequent outcomes.
\end{abstract}

\section{Keywords}

CIAM; Existenzminimum; functional city; urban housing; Zeilenbau

\section{Issue}

This commentary is part of the issue "Housing Builds Cities", edited by Luca Ortelli (École Polytechnique Fédérale de Lausanne, Switzerland), Chiara Monterumisi (École Polytechnique Fédérale de Lausanne, Switzerland) and Alessandro Porotto (École Polytechnique Fédérale de Lausanne, Switzerland).

(C) 2019 by the author; licensee Cogitatio (Lisbon, Portugal). This article is licensed under a Creative Commons Attribution 4.0 International License (CC BY).

CIAM, the Congrès Internationaux d'Architecture Moderne, was founded by a coalition of European architects in 1928. It defined itself as a forum for new design ideas, and not as a bureaucratic organization, with the result that its financial basis was always quite tenuous and reliant on individual patrons. At CIAM 2, held in Frankfurt in 1929, with representatives mostly from various northern European cities, the group took up the issue of the Existenzminimum, the family housing unit affordable on a minimum wage income (CIAM, 1930). It also began using same-scale plans to compare various minimum unit layouts by its members, illustrating the idea that previous conceptions of 'architecture', based on the use of historic precedents and intended for expensive and honorific buildings, were now obsolete. This direction was part of the Neues Bauen (New Building) in Germany, where architects like Hannes Meyer, the director of the Bauhaus from 1928-1930 and a participant at La Sarraz, had advocated that architects turn toward scientifically-based solutions to the immediate living and working conditions of the masses (Figures 1-3).

Since then, the validity of this direction for architecture has been much debated. The Existenzminimum may be CIAM's most significant concept, as the group defined it as the basic planning unit for larger structures ranging from a single building to entire regions. Individual building projects by CIAM members based on it include Wells Coates's Isokon Flats (Figure 4) in Hampstead, London, 1934, Josep Lluis Sert's, Casa Bloc in Barcelona, 1933, and Sven Markelius's Collective House in Stockholm, 1935.

At CIAM 3, held in Brussels in 1930, CIAM turned to the design of housing settlements composed of minimum units, whose form was then a subject of debate. CIAM rejected the then-standard European use of perimeter block urban housing patterns, as they argued that these did not create equal access to sunlight and good ventilation in every unit. Instead, CIAM advocated that new housing be built in widely spaced Zeilenbau rows, like those designed by Ernst May and his associates in Frankfurt, which they would also soon begin to propose for new Soviet cities like Magnitogorsk, Russia. These were to be organized into walkable 'neighbourhood units', a term first used in North American planning. Each unit would be no larger than $1 / 2$ mile $(0.81 \mathrm{~km})$ in diameter, centred on an elementary school and also including other collective services. This concept 


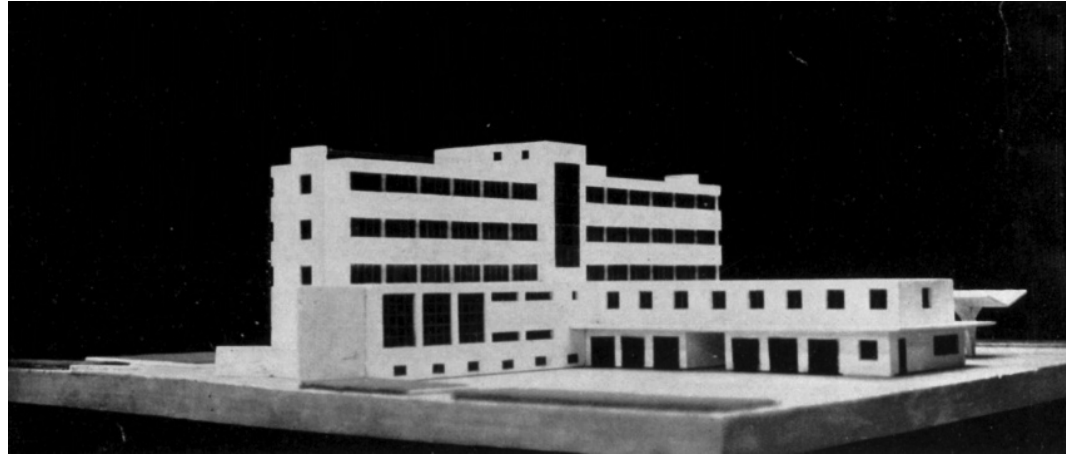

Figure 1. Model for hotel for auto tourists project, 1923, by Gabriel Guévrékian. Source: Gropius (2019, p. 50).

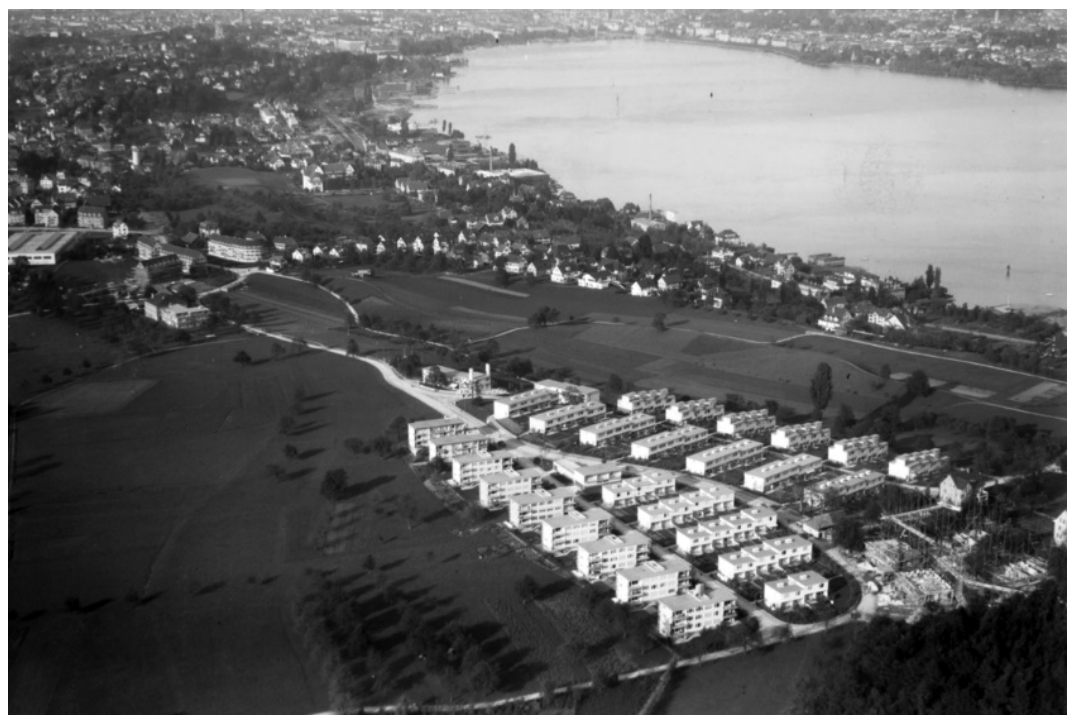

Figure 2. Neubühl housing settlement 1932, Zurich, by Swiss CIAM architects (originally published in Rationelle Bebauungweisen, 1931). This project was example \#19 from the CIAM 3 proceedings. Source: Wikimedia Commons (2007).

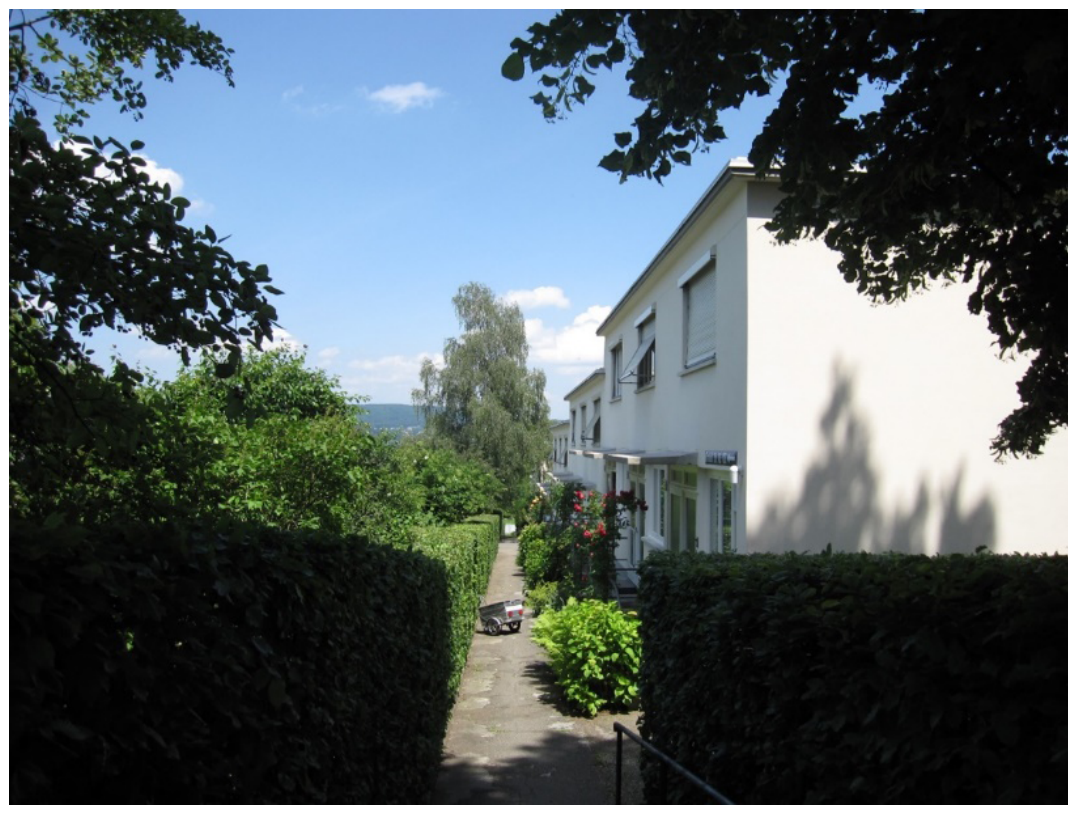

Figure 3. Neubühl housing settlement, Zurich, 1931, by Swiss CIAM architects. View of a row of minimum housing units, looking toward Lake Zurich. Source: Mumford (2009). 


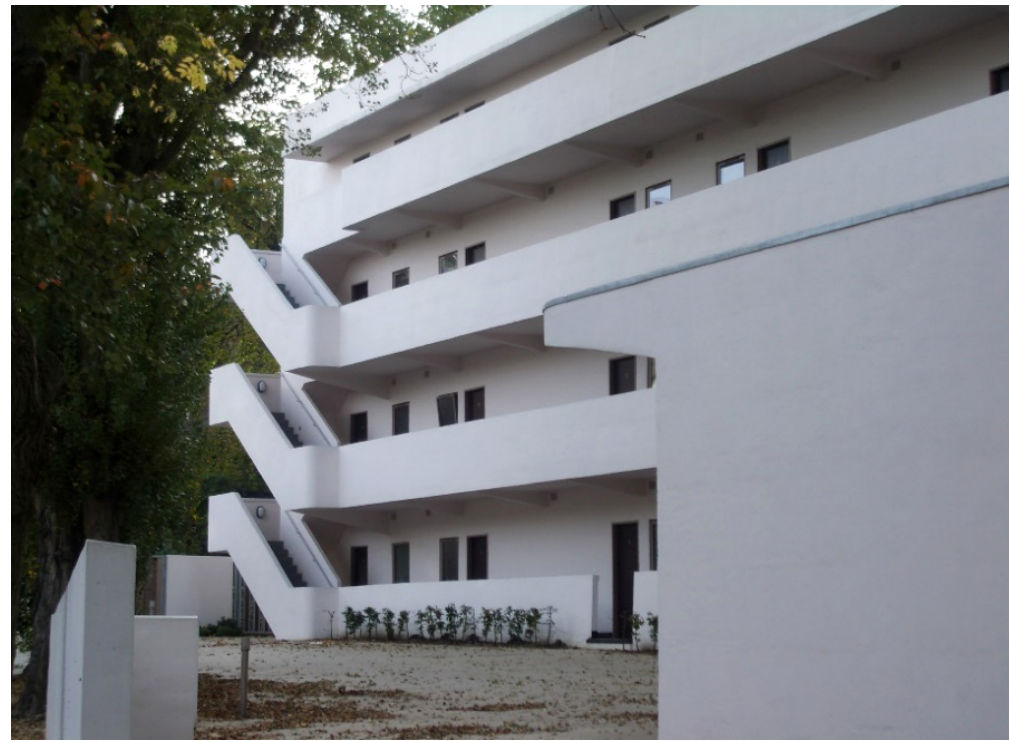

Figure 4. Wells Coates, Isokon Flats, Lawn Road, Hampstead, London, 1934. An application of the Existenzminimum idea in a lowrise collective housing block by a member of the MARS Group, with shared services. It housed Walter Gropius, Arthur Korn, and some other CIAM members in England in the mid-1930s. Source: Wikimedia Commons (2005).

was then widely applied in mass housing projects worldwide and has proved to be a durable legacy of CIAM, one that it shared with some other twentieth century planning directions.

At CIAM 3 another debate also emerged, on the suitability of high-rise building for workers' housing. High-rise elevator apartment buildings had been constructed in New York since the early 1880s. Auguste Perret and Le Corbusier in Paris each made design proposals that entire cities could be built in this way. In Le Corbusier's Contemporary City for Two Million project (1922), the cruciform towers were for offices, surrounded by 8 story housing blocks organized into walkable green superblocks bounded by high-speed traffic routes. At CIAM 3, Walter Gropius and Le Corbusier both argued that in areas of high land costs, widely spaced housing slabs with elevators were a better housing form than the more economical four story Zeilenbau (Figure 5) patterns (Gropius, 1943).

Among the reasons for this debate was the question of the nature of family life in a collectivist society. Some Soviet CIAM architects and other CIAM members like the Prague critic Karel Teige advocated new forms of communal living like the Narkomfin apartments in Moscow of Ginsburg and Milinis (1928). At the same time, this type was already being widely used for hotels and luxury housing, and soon modern architects began to make proposals for it also, as at Gropius and Fry's unbuilt project for St. Leonard's Hill, near Windsor Castle outside London (1935). Among the few built examples of a high-rise slab of minimum units like that envisioned by Gropius in 1931 by a CIAM member is Willem Van Tijen's Bergpolder Flats (Figure 6) in Rotterdam (1932-34). This debate over high versus low building was never resolved in CIAM.

\section{FOUR STAGES OF BLOCK PLANNING}

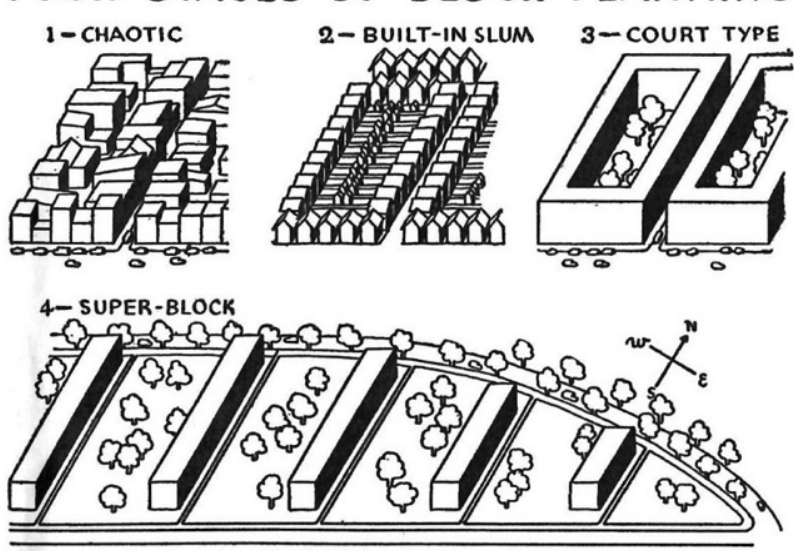

Figure 5. A 1940 diagram of Zeilenbau planning, showing its advantages for preserving open space near the housing units. Source: Reed and Ogg (1940). 


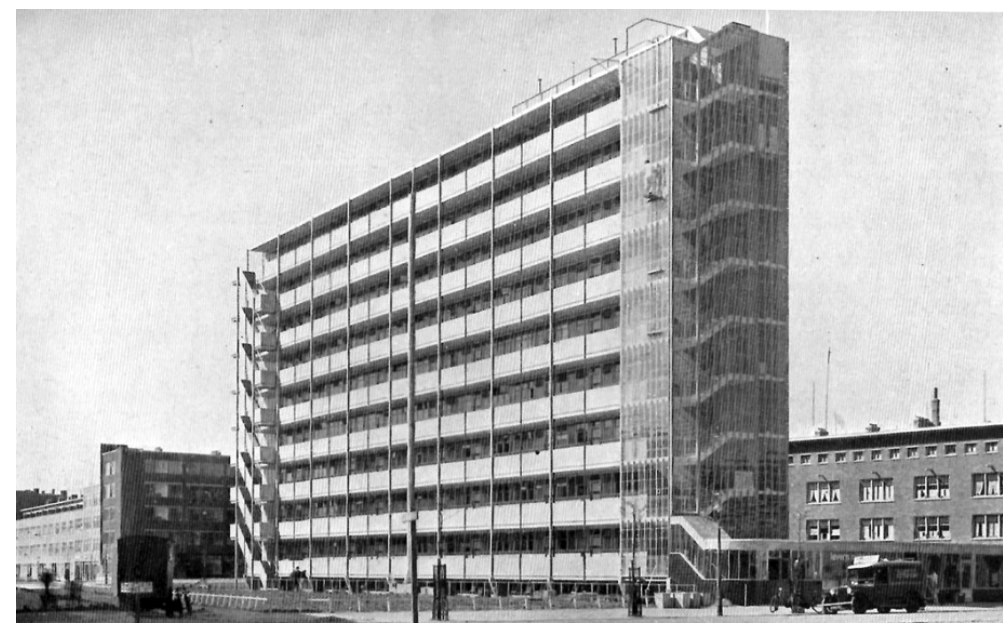

Figure 6. Willem van Tijen, with Brinkmann and Van der Vlugt, Bergpolderflat, Rotterdam, 1932-34. The first built high-rise slab by a CIAM member, and a model for the many gallery access post-war slabs of British and later housing estates. Source: Yorke \& Penn (1939, plate 15).

Much more controversial for urban planning was the CIAM idea of the Functional City, derived from Cornelis van Eesteren's Amsterdam planning, and the basis for CIAM 4 in 1933, originally planned for Moscow in 1932. Van Eesteren had rejected the large scale perimeter block planning of H. P. Berlage in Amsterdam South (1917), and instead looked to then-new North American industrial cities, which were increasingly being shaped by trucks and automobiles, as a model for what he called "Eine Stunde Städtebau" (One Hour City Building) (Van Eesteren, 1997). Van Eesteren argued that the "functional elements" of the city, primarily large factories, ports, and collective recreation spaces, could be organized in relation to housing by using the most efficient transportation routes, guided by statistical studies such as those being produced by his colleague Theodor K. Van Lohuizen. Instead of trying to thread new highways through existing cities (as he had attempted to do in a proposal for Paris in 1926, with Louis-Georges Pineau), Van Eesteren instead joined Le Corbusier in advocating the replacement of "obsolete" urban districts with new highways and housing, which he argued might be well be high-rise. Appointed President of CIAM with Gropius's support in 1930, Van Eesteren's approach was the basis of the CIAM "four functions of the city" first publically articulated at CIAM 4: dwelling, work, transportation and recreation (Figure. 7).

The CIAM Functional City approach to urbanism derived from earlier European planning, which had also attempted to structure urban environments to create a

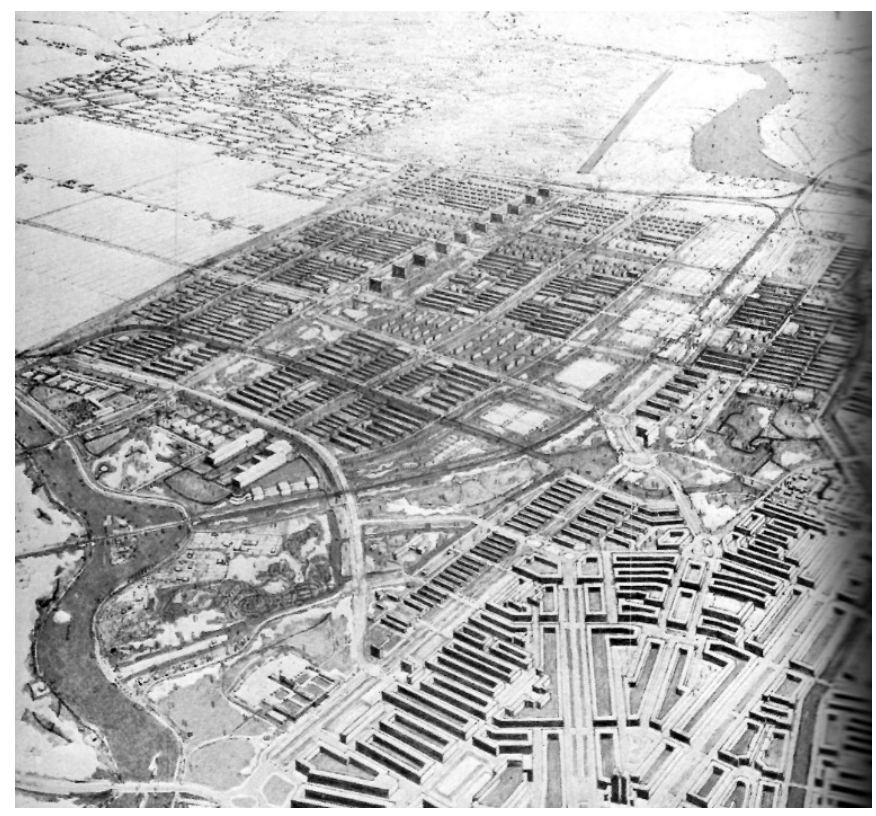

Figure 7. Amsterdam General Extension Plan, 1935, by Cornelis van Eestern and team. H.P. Berlage's Amsterdam South plan, already built out by 1935, is at the lower right. Source: Giedion (1942, p. 528). 
high quality environment for all. In the United States, the legislative aspect of these planning directions led to the widespread use of zoning ordinances in the 1920 s to mandate suburban environments of single family houses, with commercial and industrial uses then placed away from them in separate zones. This residential zoning also typically intensified racial segregation, as most nonwhite Americans were not considered eligible for home mortgages and were thus excluded for the most part from living in the detached house suburban environments then considered to be normative.

In Europe, and eventually much of the rest of the world, the Functional City approach instead tended to improve housing conditions, as workers were often given better multifamily housing environments within larger, but still relatively more compact, metropolitan areas than those of North America. In combination with earlier, related planning directions like German Städtebau and the British Garden City movement, the efforts of CIAM to improve the overcrowded and unsanitary housing conditions of industrial cities laid the basis for most subsequent European and world master planning. This involved first, the efficient design of individual units (dwelling) in blocks in neighbourhood units (Giedion, 1951) so that all had good sunlight and ventilation, with easy pedestrian access to collective facilities (recreation). These neighbourhood units were ideally linked together by transit ways and by highways (transportation) to make for shorter commutes to business and industrial areas (work). This pattern was intended to be, and often was, healthier than the dense, smoky, and unsanitary exist- ing industrial cities that had mostly been built in the late nineteenth century, which nonetheless often had more pedestrian streets and interesting architecture.

Aside from the brief CIAM moment in Soviet urbanism in 1931-32, official acceptance of these directions in most cities was quite limited before 1945 (Figure 8). In France, despite Le Corbusier's extensive propagandizing for CIAM in his many published unbuilt projects and at CIAM 5 (1937), only a few CIAM-type projects for urban districts were built in the 1930s. These included Beaudouin and Lods Cité de la Muette in Drancy, near Paris (1934, mostly demolished). CIAM influence was still present in the many Soviet housing projects built after 1932, but these were usually organized in perimeter block patterns with (in theory) collective services, a direction pioneered in Red Vienna in the 1920s, but designed within the rigid architectural framework of Soviet neoclassicism. It was only in the 1940s that CIAM Zeilenbau concepts began to widely apply to large scale urban redevelopment. These appeared both in Swedish social housing, which also began to sometimes use pitched roofs, and to include taller 'point blocks', and in other European cities, as filtered through Le Corbusier and the French CIAM group ASCORAL's La Charte d'Athènes (The Athens Charter, 1943). It was at this time also that the earlier history of CIAM began to be presented without its earlier socialist political context, with an emphasis on the economic and social rationality of CIAM solutions.

In post-war Britain, these directions were used in a range of widely varying local circumstances that ranged from high-rises for the working class in a few cities,

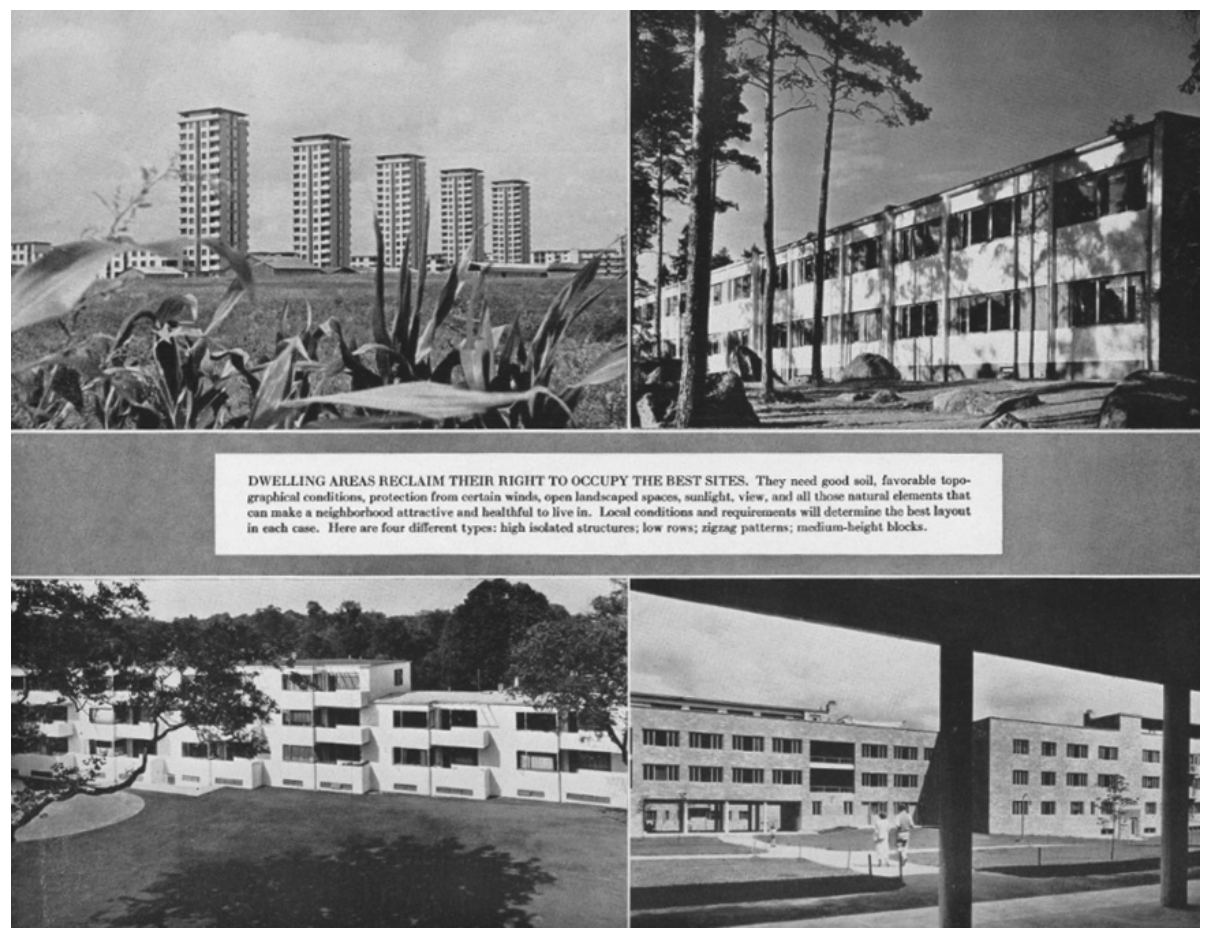

Figure 8. Examples of housing by CIAM members. Top left: Beaudouin, Lods, and Prouvé, Cité de la Muette, Drancy, near Paris, 1936. Top right: Alvar Aalto, Sunila Type B rowhouses, 1936. Bottom left: Arne Jacobsen, Bellavista Flats, Bellevue, Denmark, 1931-34. Bottom right: Stonorov and Kastner, Carl Mackley Houses, Philadelphia, 1931. Source: Sert (1942). 
notably Glasgow, to some of the more architecturallydriven housing experiments of the London County Council (Bullock, 2015). While modern housing then became the focus of intense criticism in Britain by the late 1960s, paralleling similar reactions to public housing in American cities, these CIAM-inspired also had a formative impact on the mass housing programs of the thenBritish colonies of Singapore and Hong Kong in the 1950s.

As Singapore moved toward independence, in 1959 the Housing and Development Board (HDB) was established, initially as a way of rebuilding 'squatter settlements' with one room 'minimum units' in concrete slab blocks. These paralleled similar efforts in Hong Kong, where the Hong Kong Housing Authority (HKHA) had been established after the Shek Kip Mei settlement fire in 1953. The HKHA was an outgrowth of the private philanthropic Hong Kong Housing Society, based on similar groups in London, with roots in the nineteenth century reform efforts of John Ruskin and Octavia Hill. To meet growing housing demand, the HKHA began to build very high density projects (4,000 people per acre, versus 200 people per acre in similar London projects) of single room units in seven story buildings, organized along external corridors with one bathroom per floor. By the 1960s, the HKHA was building projects that combined both low and high-rise (up to 25 story) elements, organized around open spaces with extensive communal facilities. In Singapore, as part of the 1951-58 Master Plan, the HDB began to develop the high-rise new town of Queenstown in 1961 and expanded its New Towns program in 1965. It also introduced mass social homeownership (a departure from the British local public authority ownership model) in 1964, in the 16 story slab blocks of the Queenstown Area 3. By 1987, 85\% of the popu- lation of Singapore was housed in similar governmentbuilt housing, in individually owned apartments on 99year leases. (Glendinning, 2015).

Hong Kong introduced this Singapore model of housing ownership into its government-built high-rises in the early 1970s (Figure. 9). In China after 1992, where Soviet type "work unit estates" of midrise Zeilenbau housing blocks without elevators had continued to be built near factories into the 1970s, the Singapore model of modern housing then began to be widely applied, as the country moved toward a mixed market economy under the tight control of the Communist Party.

In Western Europe by 1953, the ideas of CIAM urbanism put forward at its first eight congresses (1928-51) began to be questioned by the group of CIAM "youth members" known as Team 10, which then led to very different outcomes in urbanism. Team 10 demanded that CIAM return to using the more traditional urban categories of house, street, district, and city, and at the same time offered a different kind of master planned urbanism to facilitate street life and human associations in interconnected 'megastructures' (a term coined by Fumihiko Maki in 1964). Team 10 also rejected the urban plazas and modern monumentality of the heart of the city idea, put forward by CIAM President Sert at CIAM 8 in 1951, in favor of dispersing collective functions within the large megastructures (Figure 10). This direction was influential on many practitioners in the 1960s, including Denys Lasdun (London), Paul Rudolph (New York), and William Lim (Singapore). It was also influentially rejected, along with CIAM and modern urbanism in general, by critics like Jane Jacobs (1961) and by postmodernist architects in the 1970s. Criticisms of the CIAM Functional City first made by Team 10 members were soon taken up by oth-

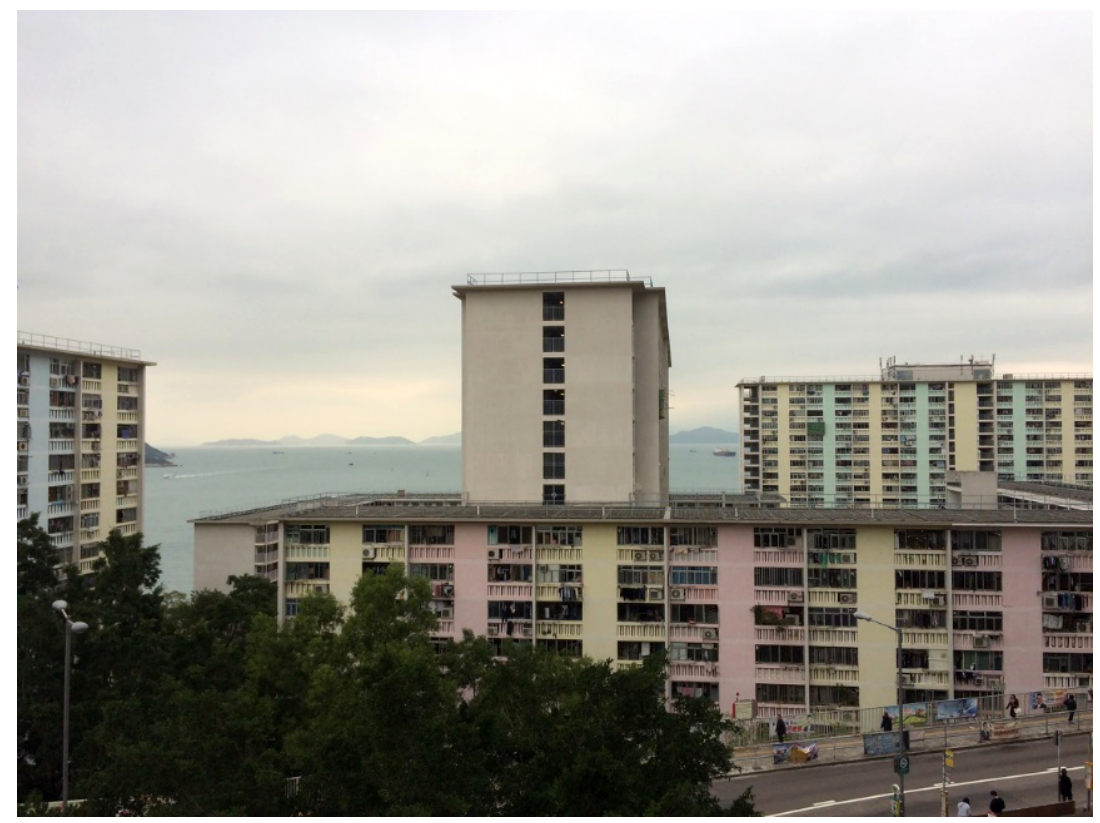

Figure 9. Hong Kong Housing Authority, by chief architect Donald Liao and others, Wah Fu development, Hong Kong, 1965-1971. Source: Mumford (2017). 


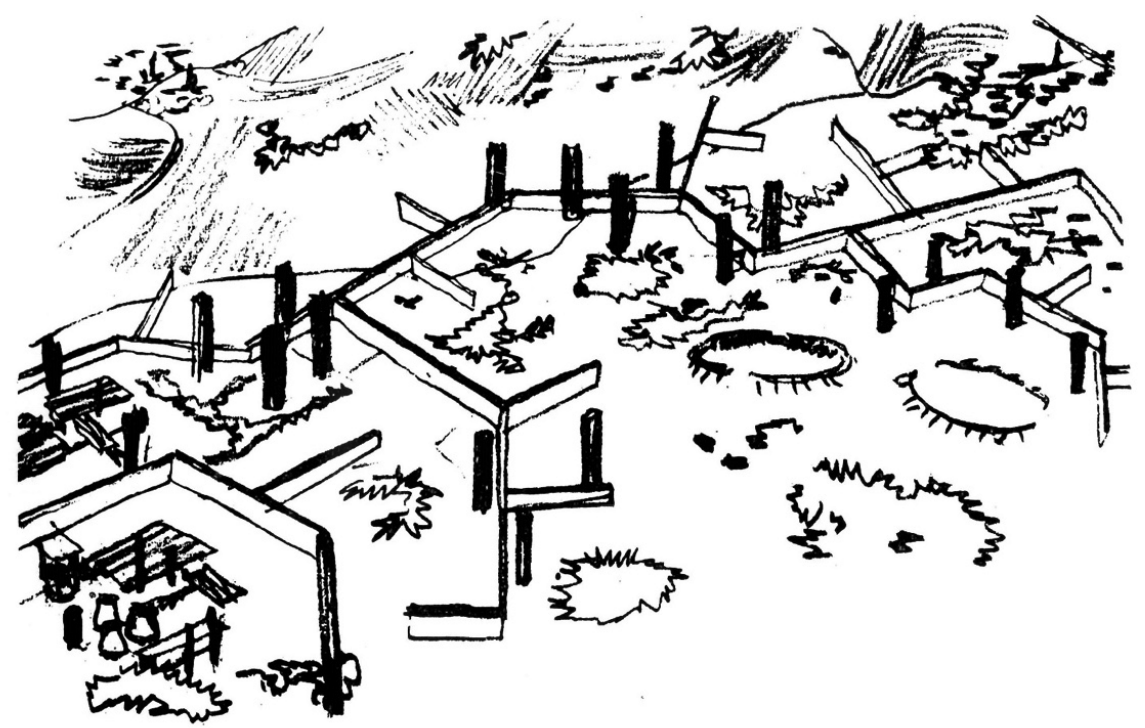

Figure 10. Golden Lane competition project panel, 1952, showing continuous interconnected housing blocks surrounded by green spaces. Presented on a CIAM Grid, CIAM 9, Aix-en-Provence. Source: Smithson and Smithson (1953).

ers in the 1960s, often in combination with protests against urban renewal, evictions, and many other issues.

In this century, with its many new urban challenges in Asia and Africa, architects and planners have again become interested in CIAM's concepts. These design approaches suggest ways that if designed well, high quality urban housing for workers can be produced economically, in combination with more contemporary concerns for the future of the natural environment.

\section{Acknowledgments}

Many thanks to the faculty of EPFL for their invitation to participate in these events and in these publications related to the 90th anniversary of CIAM.

\section{Conflict of Interests}

The author declares no conflict of interests.

\section{References}

Bullock, N. (2015). West Ham and the welfare state 19451970. In M. Swenarton, T. Avermaete, D. van den Heuvel (Eds.), Architecture and the Welfare State (pp. 93-110). London: Routledge.

CIAM. (1930). Dwellings for lowest income. Stuttgart: Julius Hoffmann.

Glendinning, M. (2015). From European welfare state to asian capitalism: The transformation of British public housing in Hong Kong and Singapore. In M. Swenarton, T. Avermaete, D. van den Heuvel (Eds.), Architecture and the Welfare State (pp. 299-320). London: Routledge.

Giedion, S. (1951). A decade of new architecture. Zurich: Editions Girsberger.

Giedion, S. (1942). Space, time, and architecture. Cam- bridge, MA: Harvard University Press.

Gropius, W. (1943). Houses, walk-ups, or high-rise apartment blocks. In W. Gropius, Scope of Total Architecture. (pp. 103-115). New York, NY: Collier Books.

Gropius, W. (2019). International architecture. Zurich: Lars Müller Publishers.

Mumford, E. (2009). Neubühl housing settlement, Zurich, 1931 by Swiss CIAM architects. View of a row of minimum housing units, looking toward Lake Zurich [Photograph].

Mumford, E. (2017). Hong Kong Housing Authority, chief architect Donald Liao and others, Wah Fu development, Hong Kong, 1965-71 [Photograph].

Reed, W. V., \& Ogg, E. (1940). New homes for old: Public housing in Europe and America. New York, NY: Foreign Policy Association.

Sert, J. L. (1942). Can our cities survive? Cambridge, MA: Harvard University Press.

Smithson, A., \& Smithson, P. (1953). Golden Lane competition project panel, 1952, showing continuous interconnected housing blocks surrounded by green spaces. Harvard University Special Collections. Cambridge, MA: Harvard University Archives.

Van Eesteren, C. (1997). The idea of the functional city. Rotterdam: NAi Publishers.

Wikimedia Commons. (2007). Neubühl housing settlement 1932. Wikimedia Commons. Retrieved from https://commons.wikimedia.org/wiki/Category: Werkbundsiedlung_Neub\%C3\%BChl\#/media/File: Neub\%C3\%BChl.jpg

Wikimedia Commons. (2005). Wells Coates, Isokon flats, Lawn Road, Hampstead, London, 1934. Wikimedia Commons. Retrieved from https://en.wikipedia.org/ wiki/Isokon_Flats\#/media/File:Isokon_Building_ Hampstead_2005.jpg

Yorke, F. R. S., \& Penn, C. T. (1939). A key to modern architecture. London: Blackie and Son Limited. 


\section{About the Author}

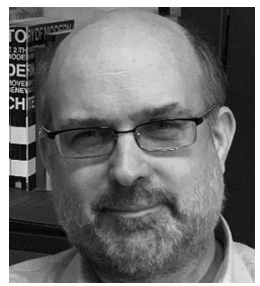

Eric Mumford (PhD) is Rebecca and John Voyles Professor of Architecture and Urban Design in the Sam Fox School of Design \& Visual Arts at Washington University in St. Louis, Missouri, USA. He has published numerous books and articles on the history and theory of modern architecture and urbanism, including The CIAM Discourse on Urbanism, 1928-1960 (MIT Press, 2000), and most recently Designing the Modern City: Urbanism since 1850 (Yale University Press, 2018). Mumford was also recently the co-curator for the exhibition, Ando and Le Corbusier, at the new Tadao Ando designed Wrightwood 659 Gallery in Chicago (Fall 2018), and he is the editor of the forthcoming exhibition catalogue. 